\title{
Nutritional and functional properties of dried Momordica cochinchinensis Spreng. fruit aril and its application in cheese spread production
}

\author{
${ }^{1, *}$ Carbonera, A.F.A., ${ }^{2}$ Tayobong, R.R.P., ${ }^{1}$ Barrameda, L.I.C. and ${ }^{1}$ Miranda, A.M.V. \\ ${ }^{1}$ Institute of Food Science and Technology, College of Agriculture and Food Science, University of the \\ Philippines Los Baños, 4031, Laguna, Philippines \\ ${ }^{2}$ Institute of Crop Science, College of Agriculture and Food Science, University of the Philippines Los \\ Baños, 4031, Laguna, Philippines
}

\author{
Article history: \\ Received: 12 May 2020 \\ Received in revised form: 13 \\ June 2020 \\ Accepted: 4 July 2020 \\ Available Online: 3 August \\ 2020

\section{Keywords:} \\ Momordica cochinchinensis, \\ $\beta$-carotene, \\ Lycopene, \\ Antioxidant activity, \\ Functional ingredient
}

\section{DOI:}

https://doi.org/10.26656/fr.2017.4(6).221

\begin{abstract}
Momordica cochinchinensis Spreng. is an underutilized fruit-bearing indigenous plant in the Philippines with great potential due to its reported nutritional properties. The aril portion of the fruit was used because of its high carotenoid content. The aril was dried using oven drying $\left(60^{\circ} \mathrm{C}\right)$ and freeze drying methods to a final moisture content of $15 \%$, and then compared in terms of its lycopene, $\beta$-carotene, and Vitamin A contents as well as antioxidant activity. To determine the potential of the dried aril as an additive to produce a fortified product, it was added at an amount of $4 \mathrm{~g}$ per $100 \mathrm{~g}$ of cheese spread then its nutritional properties were evaluated. Results showed that freeze dried aril has high $\beta$ carotene $(2090.28 \mu \mathrm{g} / \mathrm{g})$ and Vitamin A $(3483.80 \mathrm{IU} / \mathrm{g})$ but is not significantly different than the oven-dried aril while the oven-dried aril has significantly higher lycopene content $(405.22 \mu \mathrm{g} / \mathrm{g})$ than the freeze dried aril $(325.84 \mu \mathrm{g} / \mathrm{g})$. Furthermore, the freeze dried aril has significantly higher antioxidant activity (29.81\%) than the oven-dried aril (16.27\%). The addition of the dried aril to cheese spread resulted to a product with significantly higher lycopene $(30.15 \mu \mathrm{g} / \mathrm{g}), \beta$-carotene $(24.93 \mu \mathrm{g} / \mathrm{g})$, Vitamin A $(41.55 \mathrm{IU} / \mathrm{g})$, and Vitamin C $(1.20 \mathrm{mg} / 100 \mathrm{~g})$ compared to the cheese spread with no aril powder. Thus, a serving size of $1 \mathrm{tbsp}(20 \mathrm{~g})$ of the cheese spread with aril powder can provide $17 \%$ daily value for Vitamin A and has satisfied the definition of fortified food as well as the USDA standard reference for Vitamin A. This functional ingredient can therefore address concerns on Vitamin A deficiency.
\end{abstract}

\section{Introduction}

Vitamin A deficiency disorder (VADD) is one of the most common nutritional problems in less-developed and developing countries affecting children as well as adults (West, 2003). As such, it is considered a health issue in many Asian countries such as the Philippines, India, Pakistan, and Vietnam. Since Vitamin A cannot be synthesized in the body, this micronutrient should be obtained from food or supplements and many households rely on fruits and vegetables since provitamin A of plant origin are more affordable compared to preformed Vitamin A from animal sources (Faber and Jaarsveld, 2007).

Food fortification is one of the well-known public health interventions and one of the most effective methods of preventing nutritional deficiencies such as VADD. Various foods are being fortified with Vitamin
A such as milk, vegetable oils, and cereal-based products. However, a good fortificant is of utmost concern with regards to its bioavailability and possible health effects (Akhtar et al., 2013).

The M. cochinchinensis Spreng., is a tropical plant found in Asian countries such as Vietnam, Philippines, China, Malaysia, Japan, India, Thailand, Laos, Cambodia, and Bangladesh. It bears a round to oblongshaped fruit which consist primarily of the mesocarp, black seeds which is covered with the red aril, and a spiny skin (Vuong, 2001). It is commonly called as Buyok-buyok or Sugod-sugod in the Philippines and is one of the indigenous crops considered to have immense potential because of its high carotenoid content, specifically in the aril portion. The total lycopene content of the ripe fruit is reported to be $3000 \mu \mathrm{g} / \mathrm{g}$ as compared to tomatoes having only $40-50 \mu \mathrm{g} / \mathrm{g}$ (Tran et al., 2015). In addition, the $\beta$-carotene in the aril is almost ten times 
more concentrated than that of carrots (Mai et al., 2013). It also contains phenolic compounds, flavonoids, and trypsin inhibitors that have beneficial bioactivities as being antioxidants, anticancer, and provitamin A activities (Chuyen et al., 2014). However, even with its reported nutritional content, it is underutilized in the Philippines because of its seasonality as well as the lack of research and promotion. Because of this, there is no mass production of the crop and no known processed products from the fruit in the Philippines. Thus, if the potential of this fruit will be introduced, farmers may opt to consider this crop beyond backyard farming and food manufacturing companies will be encouraged to utilize the fruit and develop it into products.

In general, this plant only bears fruit in certain seasons, mainly from December to January (Vuong and King, 2003). In addition, it can easily go overripe and is prone to pest attack. Therefore, to have an all-year-round supply of fruit with retained high carotenoid content, preservation techniques must be employed and one common way is by drying. Drying, however, is also generally known to have some detrimental effects on the nutritional properties on different fruits. Thus, the objectives of the study are to examine the effect of two drying techniques on the nutritional and functional properties of the $M$. cochinchinensis fruit aril and to determine if it has the potential to be utilized as an additive to improve the nutritional and functional properties of an existing product in the market such as the cheese spread which is popular in the Philippines.

\section{Materials and methods}

\subsection{Raw material preparation}

The fruit material was collected from the Crop Management and Production Division, Institute of Crop Science, University of the Philippines Los Baños (UPLB), Philippines. Fruits of uniform red-orange color and size were harvested upon maturation, which is after two months from successful pollination. The fruits were washed, cut in half, and the aril-covered seeds were removed by scooping to separate them from the fruit pulp. The aril was collected by separating from the seeds manually, homogenized, placed and sealed in polyethylene bags, and stored in the freezer until use.

\subsection{Drying of fruit aril}

The collected aril was portioned to two, one portion was subjected to oven drying (Memmert Oven Dryer UF 750 ) at $60^{\circ} \mathrm{C}$ for $24 \mathrm{hrs}$, while the other portion was subjected to freeze drying (ULVAC freeze dryer DF01H, MFG No. MF61-9314) with the following conditions: $40^{\circ} \mathrm{C}$ heating, $-19^{\circ} \mathrm{C}$ cooling, and 0.4 Torr pressure for $18 \mathrm{hrs}$. The final moisture content of the aril was lowered down to $15 \%$ and determined using ovendrying method (AOAC - 930.15). The dried aril was collected, powdered using a grinder (KRUPS F203), and allowed to pass a 20 mesh sieve (Tyler standard screen scale testing sieve, USA series) to obtain uniform sized particles.

\subsection{Determination of $\beta$-carotene, Vitamin $A$, and lycopene contents}

The $\beta$-carotene content was determined using the Shimadzu UV Mini-1240 UV-VIS spectrometer following the methods of Harborne (1973) as cited by Lakra et al. (2018) with acetone: hexane (3:7) as the extraction solvent and $\beta$-carotene (Fluka BioChemika 22040) solutions as standard. Absorbance reading was done at $440 \mathrm{~nm}$ against a blank. The $\beta$-carotene and Vitamin A contents were calculated as follows, wherein 1 I.U. of Vitamin A is equivalent to $0.6 \mu \mathrm{g} \beta$-carotene:

$$
\begin{gathered}
\beta-\text { carotene }=\frac{(\text { conc. from standard curve })(\text { vol. sample })}{\text { weight of sample }} \times 100 \\
\text { Vitamin } A=\frac{\text { calculated } \beta-\text { carotene }}{0.6}
\end{gathered}
$$

Lycopene content was also determined using the Shimadzu UV Mini-1240 UV-VIS spectrometer following the methods of Fish et al. (2002) using hexane:ethanol: acetone $(1: 1: 2)$ as the extracting solvent. The absorbance reading of the non-aqueous portion was read at $503 \mathrm{~nm}$ against a blank and the lycopene content was calculated using the formula:

$$
\text { Lycopene }=\frac{\left(\mathrm{Abs}_{503} \times 537 \times 8 \times 0.55\right)}{0.10 \times 172}
$$

Where $537 \mathrm{~g} /$ mole $=$ molecular weight of lycopene, 8 $\mathrm{mL}=$ volume of extracting solvent, $0.55=$ volume ratio of the upper layer to the extracting solvent, $0.10 \mathrm{~g}=$ weight of sample, $172 \mathrm{mM}^{-1}=$ extraction coefficient for lycopene in hexane

\subsection{Antioxidant activity determination}

The free radical scavenging activity was determined using 1,1-diphenyl-2-picryl hydrazyl (DPPH) (Sigma) following the protocol of Shekhar and Anju (2014) with some modifications. The sample extract was prepared by adding $20 \mathrm{~mL}$ methanolic solution $(50 \%)$ to $2 \mathrm{~g}$ of the powdered samples and shaken for $1 \mathrm{hr}$. Approximately 1 $\mathrm{mL}$ of the sample extract was added with $4 \mathrm{~mL} \mathrm{dH}_{2} \mathrm{O}$ and $1 \mathrm{~mL}$ DPPH solution ( $1 \mathrm{mM})$, allowed to stand in the dark for 30 mins, and the absorbance was read at $517 \mathrm{~nm}$ using the Shimadzu UV Mini-1240 UV-VIS spectrometer. A control test was also prepared accordingly. The \% scavenging activity was calculated as:

Scavenging activity $=\frac{\mathrm{Abs}_{\text {control }}-\mathrm{Abs}_{\text {sample }}}{\mathrm{Abs}_{\text {control }}} \times 100$ 


\subsection{Statistical analysis}

Using Design-Expert ${ }^{\circledR}$ version 10 , results from the determination of $\beta$-carotene, Vitamin $\mathrm{A}$, and lycopene contents of the fresh, oven-dried, and freeze dried aril were subjected to ANOVA and the results with significant differences were subjected to the post hoc test Tukey HSD. While the results for the nutritional composition of the cheese spread was subjected to T-test.

\subsection{Production of cheese spread}

The cheese spread was prepared by pasteurizing $750 \mathrm{~mL}$ of full cream cow's milk. Before the milk boils, $1 \mathrm{~kg}$ of grated commercially processed cheddar cheese was added gradually. The cheese was allowed to melt over low heat with continuous stirring. The mixture was removed from heat and the powdered aril was added in the ratio of $4 \mathrm{~g}$ per $100 \mathrm{~g}$ cheese spread with continuous stirring to achieve uniform color. The amount of dried aril was based on a preliminary study wherein $4 \%$ added aril powder will result to a vitamin A content of at least $15 \%$ in the final product, the minimum amount for it to be called a fortified food. The cheese spread was then transferred and stored in sterilized containers. Another batch with no added aril was also prepared and served as the control.

\subsection{Nutritional analysis of cheese spread}

The cheese spread with and without added aril powder (control) was analyzed and compared in terms of its nutritional properties. The proximate composition was determined using standard methods of AOAC (2005). Moisture content was determined by oven-drying method (AOAC - 930.15), ash content by dry ashing (AOAC 923.03), fat by Soxhlet method (AOAC - 945.16) using petroleum ether as the extracting solvent, protein by Kjeldahl method (AOAC - 920.87), total carbohydrates will be represented by nitrogen free extract (NFE) which was calculated by difference, total sugars by phenolsulfuric acid method (Nowotny, 1979; Afsharnezhad et al., 2017) using glucose as standard (Sigma), and Vitamin $\mathrm{C}$ was determined by dye titration method using 2,6-dicholorophenolindophenol (Sigma) with some modifications (Ugbe et al., 2017).

\section{Results and discussion}

$3.1 \beta$-carotene, vitamin A, and lycopene contents of dried fruit aril

In order to increase the aril's shelf life which can then be used as a functional ingredient, it was dried and converted to powder form (Figure 1). As reported by Tanongkankit et al. (2014), drying at $60^{\circ} \mathrm{C}$ is recommended for the fruit aril since it provided the highest retention for the carotenoid content. Thus, it was the temperature used for oven drying and then compared the freeze dried aril as well as the fresh aril to determine the chemical changes caused by the drying process.

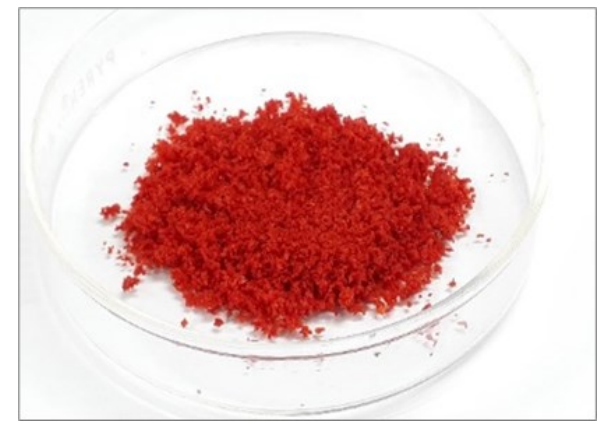

Figure 1. Dried M. cochinchinensis aril

It can be observed in Table 1 that the lycopene, $\beta$ carotene, and Vitamin A contents of the oven-dried aril were higher compared to the fresh aril. This is because freeze drying and oven drying removed the moisture content of the aril which is $85 \%$ water, thus concentrating the other components.

The lycopene content in the oven-dried aril is significantly higher compared to the freeze dried aril since heat disrupts the protein-lycopene bonding and results in a more accessible and increased cisconfiguration of lycopene making it more bioavailable (Stahl and Sies, 1992; Mendelová et al., 2013). A similar trend was observed in a study conducted by Chang et al. (2006) on freeze dried and oven-dried $\left(25-75^{\circ} \mathrm{C}\right)$ tomato pulp, it was observed that freeze drying has a negative impact on lycopene content wherein it was reduced to 33 $-48 \%$ while drying at $60^{\circ} \mathrm{C}$ increased the lycopene content by $152-197 \%$.

On the other hand, the $\beta$-carotene and Vitamin A contents of the freeze dried aril was higher compared to the oven-dried aril but is not significantly different. The two are directly related since $\beta$-carotene is the precursor of Vitamin A. Oven drying can only be employed up to a

Table 1. Lycopene, $\beta$-carotene, and Vitamin A contents of dried M. cochinchinensis aril compared to fresh aril

\begin{tabular}{lccc}
\hline Treatment & Lycopene, $\mu \mathrm{g} / \mathrm{g}$ & $\beta$-carotene, $\mu \mathrm{g} / \mathrm{g}$ & Vitamin A, IU/g \\
\hline Fresh & $204.54 \pm 5.08^{\mathrm{c}}$ & $727.80 \pm 1.70^{\mathrm{b}}$ & $1,213 \pm 2.84^{\mathrm{b}}$ \\
Freeze dried & $325.84 \pm 6.87^{\mathrm{b}}$ & $2,090.28 \pm 12.35^{\mathrm{a}}$ & $3,483.80 \pm 20.58^{\mathrm{a}}$ \\
Oven-dried $\left(60^{\circ} \mathrm{C}\right)$ & $405.22 \pm 2.33^{\mathrm{a}}$ & $1,989.18 \pm 7.49^{\mathrm{a}}$ & $3,315.30 \pm 12.48^{\mathrm{a}}$ \\
\hline
\end{tabular}

Means followed by the same letter superscript in a column indicate values that are not significantly different at $5 \%$ level of significance. 
certain temperature since higher temperature $\left(>60^{\circ} \mathrm{C}\right)$ may result in the reduction of $\beta$-carotene due to degradation caused by thermal destruction and enzymatic reaction. Baysal and Demirdoven (2007) reported that a temperature higher than $60^{\circ} \mathrm{C}$ can accelerate the lipoxygenase activity, which is responsible for the oxidative degradation of $\beta$-carotene and loss of carotenoids. At higher temperature, heat also penetrates the plant tissues that result in more degradation of $\beta$ carotene (Suvarnakuta et al., 2005; Thakur, 2018).

\subsection{Antioxidant activity of dried fruit aril}

As shown in Figure 2, it can be observed that the fresh aril still has the highest antioxidant activity with no significant difference with the freeze-dried aril but the oven-dried aril has a significant reduction in antioxidant activity.

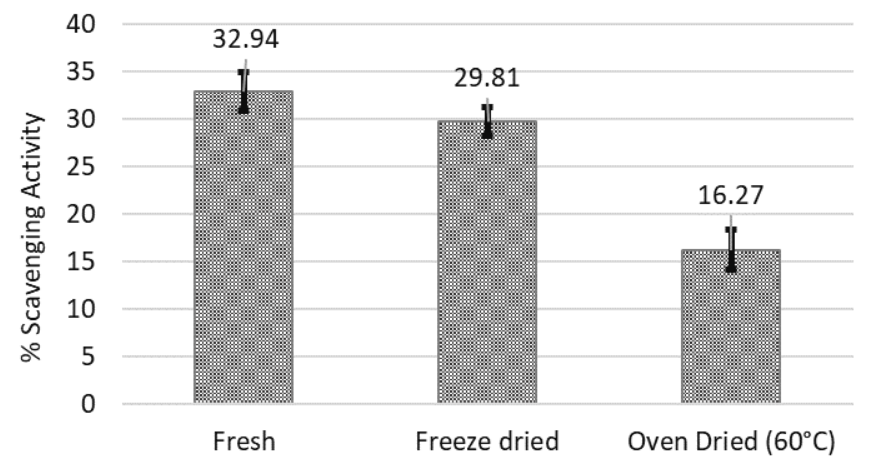

Figure 2. Antioxidant activity of dried M. cochinchinensis aril compared to fresh aril

Although oven drying led to an increase of the carotenoid contents which are known antioxidants, this does not necessarily mean that its biological activity is retained. Heat application by drying will result in a significant loss of antioxidant activity since thermal treatment can destroy some bioactive compounds (Kha et al., 2011). This is also in agreement with the research of Chantaro et al. (2008) on the effects of various hot air drying temperatures on the antioxidant capacity of carrot peel powder. Their results indicated that an air-drying temperature of $60^{\circ} \mathrm{C}$ could still preserve some antioxidant activity in the powder but will be significantly reduced at temperatures of $70^{\circ} \mathrm{C}$ or higher.

\subsection{Nutritional and functional properties of cheese spread with dried fruit aril}

The obtained data suggest that the aril can be converted to powder form by either freeze drying or oven drying at $60^{\circ} \mathrm{C}$ since the lycopene, $\beta$-carotene, and Vitamin A contents are increased while the antioxidant activity is still significantly present.

Since the oven-dried aril powder has higher lycopene content, with no significant difference in terms of $\beta$ - carotene and vitamin A as compared to freeze-dried aril powder, it was chosen as an additive for cheese spread in order to improve its nutritional properties. In addition, the oven drying method can be easily employed and has cheaper production cost if this technology will be adapted. As shown in Figure 3, two spreads were made, one with no added aril powder (control) and one with added aril powder. The product with added aril powder has a bright orange color, has a spreadable consistency, and still has the typical cheese smell.

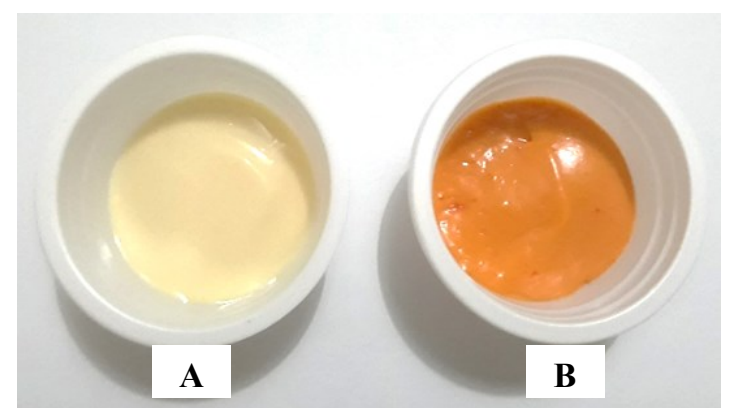

Figure 3. Cheese spread with no added aril powder (A) and with added aril powder (B)

Table 2 shows the proximate composition of cheese spread with and without added aril powder. The cheese spread with added aril powder have significantly higher ash, crude fat, crude fiber, crude protein, and NFE. On the other hand, there is no significant difference in terms of the total sugar content (Table 3) since the amount of milk and cheddar cheese added was the same. As required by the FDA, cheese spreads must contain more than $44 \%$ moisture content but not more than $60 \%$, thus the value obtained $(58.10 \%)$ is within the reference standard. The slightly higher calculated values of the cheese spread with aril powder is due to the composition of the added aril. As reported, the aril portion of the fruit has $1.65 \mathrm{~g}$ ash content per $100 \mathrm{~g}$ edible portion (Abdulqader et al., 2019) which includes calcium, phosphorus, potassium, and sodium (Nagarani et al., $2014), 0.09-7.9 \%$ fat content, $1.8 \%$ fiber content, $0.84-$ $2.1 \%$ protein content, and $9.2-10.5 \%$ carbohydrates (Vuong, 2001; Abdulqader et al., 2019).

Table 2. Proximate composition of cheese spreads without and with aril powder.

\begin{tabular}{lcc}
\hline $\begin{array}{c}\text { Composition, } \\
\%\end{array}$ & No added aril powder & $\begin{array}{c}\text { With added aril } \\
\text { powder }\end{array}$ \\
\hline Moisture & $59.10 \pm 0.26^{\mathrm{a}}$ & $58.10 \pm 0.13^{\mathrm{a}}$ \\
Ash & $4.20 \pm 0.07^{\mathrm{b}}$ & $4.46 \pm 0.03^{\mathrm{a}}$ \\
Crude Fat & $15.64 \pm 0.64^{\mathrm{b}}$ & $16.92 \pm 0.66^{\mathrm{a}}$ \\
Crude Fiber & $0.37 \pm 0.11^{\mathrm{b}}$ & $0.50 \pm 0.27^{\mathrm{a}}$ \\
Crude Protein & $14.11 \pm 0.23^{\mathrm{b}}$ & $15.58 \pm 1.46^{\mathrm{a}}$ \\
NFE & 2.36 & 3.14 \\
\hline
\end{tabular}

Means followed by the same letter superscript in a row indicate values that are not significantly different from each other using T-test 
Table 3. Total sugars of cheese spreads without and with aril powder

\begin{tabular}{lcc}
\hline Component & No added aril powder & $\begin{array}{c}\text { With added aril } \\
\text { powder }\end{array}$ \\
\hline $\begin{array}{l}\text { Total Sugars, } \\
\mathrm{mg} / 100 \mathrm{~g}\end{array}$ & $14.72 \pm 2.74^{\mathrm{a}}$ & $15.64 \pm 1.18^{\mathrm{a}}$ \\
\hline
\end{tabular}

Means followed by the same letter superscript in a row indicate values that are not significantly different from each other using T-test

In addition, the cheese spread with added aril powder has significantly higher lycopene, $\beta$-carotene, Vitamin A, and Vitamin $\mathrm{C}$ contents (Table 4). This is because the aril retained significant amounts of lycopene, $\beta$-carotene, and Vitamin A content even after drying as presented in Table 1. The USDA standard reference for vitamin A in $100 \mathrm{~g}$ of cheese spread is 653IU and the cheese spread with added aril has $4155 \mathrm{IU}$ Vitamin A per $100 \mathrm{~g}$, which is higher than the standard reference. On the other hand, the Vitamin $\mathrm{C}$ is low since the aril part is reported to contain more of the fat-soluble vitamins $\mathrm{A}, \mathrm{D}, \mathrm{E}$, and $\mathrm{K}$ (Kha et al., 2013). It must also be noted that Vitamin C is considered as the least stable among the vitamins and the loss of Vitamin $\mathrm{C}$ may be due to the drying of the aril.

Table 4. Lycopene, $\beta$-carotene, Vitamin A, and Vitamin C contents of cheese spreads without and with aril powder

\begin{tabular}{lcc}
\hline \multicolumn{1}{c}{ Component } & No added aril powder & $\begin{array}{c}\text { With added aril } \\
\text { powder }\end{array}$ \\
\hline $\begin{array}{l}\text { Lycopene, } \mu \mathrm{g} / \mathrm{g} \\
\beta \text {-carotene, }\end{array}$ & $10.71 \pm 2.30^{\mathrm{b}}$ & $30.15 \pm 4.59^{\mathrm{a}}$ \\
$\mu \mathrm{g} / \mathrm{g}$ & $0.00 \pm 0.00^{\mathrm{b}}$ & $24.93 \pm 4.01^{\mathrm{a}}$ \\
Vitamin A, & $0.00 \pm 0.00^{\mathrm{b}}$ & $41.55 \pm 6.68^{\mathrm{a}}$ \\
$\mathrm{IU} / \mathrm{g}$ & $0.28^{\mathrm{b}}$ & $1.20 \pm 0.16^{\mathrm{a}}$ \\
Vitamin C, & $\mathrm{mg} / 100 \mathrm{~g}$ &
\end{tabular}

Means followed by the same letter superscript in a row indicate values that are not significantly different from each other using T-test

\subsection{Nutrition facts of cheese spread with dried fruit aril}

The nutrition facts of the cheese spreads were also established and presented in Figures 4 and 5. The two cheese spreads have the same values except for the $\%$ DV that Vitamin A can provide which is considerably higher in the cheese spread with aril powder.

According to Dary and Mora (2002), fortified food should provide 15 to $30 \%$ of the recommended daily intakes per serving. Therefore, the value for Vitamin A in the cheese spread with the aril powder falls within the range of fortification. On the other hand, the Vitamin $\mathrm{C}$ content of both samples was computed as less than $2 \%$ of the RDI level therefore both were not a significant source of Vitamin C.

\begin{tabular}{|c|c|c|}
\hline \multicolumn{3}{|l|}{ Nutrition Facts } \\
\hline \multicolumn{3}{|c|}{ Serving Size 1 tbsp (20g) } \\
\hline \multirow{2}{*}{\multicolumn{3}{|c|}{$\begin{array}{l}\text { Calories (kcal): } 40 \\
\text { Calories from fat (kcal): } 25\end{array}$}} \\
\hline & & \\
\hline & Per Serving & $\% \mathrm{DV}^{*}$ \\
\hline Fat $(\mathrm{g})$ & 3 & 8 \\
\hline Carbohydrates (g) & 0 & 0 \\
\hline Fiber (g) & 0 & \\
\hline Sugars $(g)$ & 0 & \\
\hline Protein $(\mathrm{g})$ & 3 & 6 \\
\hline Vitamin A & & 0 \\
\hline Vitamin C & & 0 \\
\hline
\end{tabular}

Figure 4. Nutrition facts of cheese spread with no aril powder

\begin{tabular}{|c|c|c|}
\hline \multicolumn{3}{|c|}{$\begin{array}{l}\text { Nutrition Facts } \\
\text { Serving Size } 1 \mathrm{tbsp}(20 \mathrm{~g})\end{array}$} \\
\hline \multicolumn{3}{|c|}{$\begin{array}{l}\text { Calories (kcal): } 40 \\
\text { Calories from fat (kcal): } 25\end{array}$} \\
\hline & Per Serving & \%DV* \\
\hline Fat (g) & 3 & 8 \\
\hline Carbohydrates (g) & 0 & 0 \\
\hline Fiber $(\mathrm{g})$ & 0 & \\
\hline Sugars (g) & 0 & \\
\hline Protein $(\mathrm{g})$ & 3 & 6 \\
\hline Vitamin A & & 17 \\
\hline Vitamin $\mathrm{C}$ & & 0 \\
\hline
\end{tabular}

Figure 5. Nutrition facts of cheese spread with aril powder.

\section{Conclusion}

The aril portion of the Philippine indigenous fruit $M$. cochinchinensis was dried to improve its storage properties and convert it into a functional ingredient. Freeze drying and oven drying at $60^{\circ} \mathrm{C}$ were compared and both methods concentrated the material which led to an increase in its compositional content. Freeze-dried aril has higher $\beta$-carotene and Vitamin A content than the oven-dried $\left(60^{\circ} \mathrm{C}\right)$ aril, but is not significantly different. In addition freeze, dried aril also has higher antioxidant activity but the oven-dried aril has higher lycopene content. Based on the obtained results, both methods of drying can be recommended since either has significantly increased or maintained the aril's nutritional properties. However, if it will be applied to the household or commercial production, oven drying method at $60^{\circ} \mathrm{C}$ is recommended since the major nutritional properties have no significant difference over that of freeze-dried aril. The drying method can also be easily employed at a lower cost compared to freeze drying method. The addition of the oven-dried aril $(4 \mathrm{~g}$ per $100 \mathrm{~g}$ product) to a commercially existing product (cheese spread) resulted to an increase in its proximate composition and has further improved the product having higher lycopene, $\beta$-carotene, Vitamin $\mathrm{A}$, and Vitamin $\mathrm{C}$ contents. The product is considered as a Vitamin A fortified product since it can provide $17 \%$ 
Vitamin A of the recommended daily intakes per serving.

\section{Conflict of interest}

The authors declare no conflict of interest.

\section{Acknowledgments}

The research was funded by the Philippine Department of Agriculture - Bureau of Agricultural Research (Philippine DA-BAR). In addition, the Institute of Crop Science of UPLB is the research collaborator.

\section{References}

Abdulqader, A., Ali, F., Ismail, A. and Esa, N.M. (2019). Antioxidant compounds and capabilities of Gac (Momordica cochinchinensis Spreng) fruits. Asian Pacific Journal of Tropical Biomedicine, 9(4), 158167. https://doi.org/10.4103/2221-1691.256729

Afsharnezhad, M., Shahangian, S.S. and Sariri, R. (2017). Evaluation of the antioxidant activity of extracts from some fruit peels. Caspian Journal of Environmental Sciences, 15(3), 213-222.

Akhtar, S. Ahmed, A., Randhawa, M.A., Atukorala, S. Arlappa, N.M. Ismail, T. and Ali, Z. (2013). Prevalence of Vitamin A Deficiency in South Asia: Causes, Outcomes, and Possible Remedies. Journal of Health, Population, and Nutrition, 31(4), 413-423. https://doi.org/10.3329/jhpn.v31i4.19975

AOAC. (2005). Official methods of Analysis of the Association of AOAC International. $18^{\text {th }}$ ed., Maryland, USA: AOAC International.

Baysal, T. and Demirdoven, A. (2007). Lipoxygenase in fruits and vegetables: A review. Enzyme and Microbial Technology, 40(4), 491-496. https:// doi.org/10.1016/j.enzmictec.2006.11.025

Chang, C.H., Chang, C.Y. and Lui, Y.C. (2006). Comparison on antioxidant properties of fresh, freeze-dried, and hot-air dried tomatoes. Journal of Food Engineering, 77(3), 478-485. https:// doi.org/10.1016/j.jfoodeng.2005.06.061

Chantaro, P., Devahastin, S. and Chiewchan, N. (2008). Production of antioxidant high dietary fiber powder carrot peels. Journal of Pharmaceutical Sciences, 97 (12), 5089-5105.

Chuyen, H.V., Nguyen, M.H., Roach, P.D., Golding, J.B. and Parks, S.E. (2014). Gac fruit (Momordica cochinchinensis Spreng.): a rich source of bioactive compounds and its potential health benefits. International Journal of Food Science and Technology, 50(3), 567-577. https://doi.org/10.1111/ ijfs. 12721
Dary, O. and Mora, J.O. (2002). Food fortification to reduce vitamin A deficiency: International Vitamin A Consultative Group recommendations. The Journal of Nutrition, 132(Suppl. 9), 2927S-2933S. https://doi.org/10.1093/jn/132.9.2927S

Faber, M. and Jaarsveld, P.J. (2007). The production of provitamin A-rich vegetables in home-gardens as a means of addressing vitamin A deficiency in rural African communities. Journal of the Science of Food and Agriculture, 87(3), 366-377. https:// doi.org/10.1002/jsfa.2774

Fish, W.W., Perkins-Veazie, P. and Collins, J.K. (2002). A qualitative assay for lycopene that utilizes reduced volumes of organic solvents. Journal of Food Composition and Analysis, 15(3), 309-317. https:// doi.org/10.1006/jfca.2002.1069

Harborne, J.B. (1973). Phytochemical methods. London, England: Chapman and Hall.

Kha, T.C., Nguyen, M.H. and Roach, P.D. (2011). Effects of pre-treatments and air drying temperatures on color and antioxidant properties of Gac fruit powder. International Journal of Food Engineering, 7(3), 1-17. https://doi.org/10.2202/1556-3758.1926

Kha, T., Nguyen, M., Roach, P., Parks, S. and Stathopoulos, C. (2013). Gac fruit: nutrient and phytochemical composition, and options for processing. Food Reviews International, 29(1), 92106. https://doi.org/10.1080/87559129.2012.692141

Lakra, A., Trivedi, J., Sharma, D. and Dikshit, A. (2018). Spectrophotometric analysis of different genotypes of tomato fruit for different pigments. Bulletin of Environment, Pharmacology and Life Sciences, 7(2), 73-78.

Mai, H., Truing, V., Haut, B. and Debaste, F. (2013). Impact of limited drying on Momordica cochinchinensis Spreng. aril carotenoids content and antioxidant activity. Journal of Food Engineering, 118(4), 358-364. https://doi.org/10.1016/ j.jfoodeng.2013.04.004

Mendelová, A., Medel, L., Fikselová, M. and Czako, P. (2013). Effect of drying temperature on lycopene content of processed tomatoes. Potravinarstvo Scientific Journal for Food Industry, 7(1), 141-145. https://doi.org/10.5219/300

Nagarani, G., Abirami, A. and Siddhuraji, P. (2014). Food prospects and nutraceutical attributes of Momordica species: A potential tropical bioresources - A review. Food Science and Human Wellness, 3(3-4), 117-126. https://doi.org/10.1016/ j.fshw.2014.07.001

Nowotny A. (1979). Basic Exercises in Immunochemistry. Berlin, Heidelberg: Springer. 
https://doi.org/10.1007/978-3-642-67356-6

Shekhar, T.C. and Anju, G. (2014). Antioxidant activity by DPPH radical scavenging method of Ageratum conyzoides Linn. leaves. American Journal of Ethnomedicine, 1(4), 244-249.

Stahl, W. and Sies, H. (1992). Uptake of lycopene and its geometrical isomers is greater from heat-processed than from unprocessed tomato juice in humans. Journal of Nutrition, 122(11), 2161-2166. https:// doi.org/10.1093/jn/122.11.2161

Suvarnakuta, P., Devahastin, S. and Mujumdar, A. (2005). Drying Kinetics and $\beta$-Carotene Degradation in Carrot Undergoing Different Drying Processes. Journal of Food Science, 70(8), 520-526. https:// doi.org/10.1111/j.1365-2621.2005.tb11528.x

Tanongkankit, Y., Sutthanphan, T., Kaewanas, J., Poonnoy, P. and Narkprasom, K. (2014). Evolutions of $\beta$-carotene and lycopene in natural food colorant from Gac (Momordica cochinchinensis Spreng.) arils during drying. $20143^{\text {rd }}$ International Proceedings of Chemical, Biological and Environmental Engineering, 71, 56-60.

Thakur, N. (2018). Het stability and antioxidant potential of beta-carotene isolated from a fungal isolate. Bulgarian Journal of Agricultural Science, 24(5), 891-896.

Tran, X., Parks, S., Roach, P. Golding, J. and Nguyen, M. (2015). Effects of maturity on physicochemical properties of Gac fruit (Momordica cochinchinensis Spreng.). Food Science and Nutrition, 4(2), 305-314. https://doi.org/10.1002/fsn3.291

Ugbe, F.A., Ikudayisi, V.A. and Amusan, O.T. (2017). Determination of ascorbic acid concentration of some commercial fruits juices sold in Ugbokolo Benue State, Nigeria. International Annals of Science, 3(1), 19-22. https://doi.org/10.21467/ ias.3.1.19-22

Vuong, L. (2001). Gac: A fruit from heaven. Nutrition in Vietnam: Historical Topics and Contemporary Research Opportunities. Retrieved from website: http://www.biblio.nhat-nam.ru/Gac.pdf

Vuong, L. and King, J. (2003). A method of preserving and testing the acceptability of gac fruit oil, a good source of beta-carotene and essential fatty acids. Food Nutrition Bulletin, 24(2), 224-230. https:// doi.org/10.1177/156482650302400216

West, K.P. (2003). Vitamin A deficiency disorders in children and women. Food and nutrition bulletin, 24 (Suppl. 4), 78-90. https:// doi.org/10.1177/15648265030244S204 